\title{
Discerning Devotion: Testing the Signaling Theory of Religion
}

\begin{abstract}
Religious rituals often entail significant investments of time, energy, and money, and can risk bodily harm. Instead of being evolutionarily inexplicable, such costly religious acts have been argued to be honest signals of commitment to the beliefs and values of the community, helping individuals establish good reputations and foster trusting, cooperative relationships. Most tests of this hypothesis have evaluated whether religious signalers are more prosocial; here I investigate whether signal receivers actually perceive religious signalers as such. I do this with data collected over 20 months of ethnographic fieldwork in two villages in South India, where Hindu and Christian residents engage in different modes of religious practice, including dramatic acts of firewalking and spirit possession as well as the more subtle but consistent act of worshipping at a church or temple each week. Each mode of religious practice is found to be informative of a distinct set of reputational qualities. Broadly speaking, in the long term, individuals who invest more in the religious life of the village are not only seen as more devout, but also as having a suite of prosocial, other-focused traits. In the short term, individuals who perform greater and costlier acts in the annual Hindu festival show a slight increase in the percent of villagers recognizing them as physically strong and hardworking. These results suggest that people are attending to the full suite of religious acts carried out by their peers, using these signals to discern multiple aspects of their character and intentions.
\end{abstract}

Keywords: signaling theory, religion, reputation, communication, India

\section{Introduction}

In recent years, a number of evolutionary scientists have posed for themselves a sizable question: with all the costs (physical, monetary, emotional, psychological) associated with religious belief and behavior, what accounts 
for its ubiquity? Some of these researchers have sought to explain religion by delineating how certain aspects of our cognitive architecture may predispose us to believe in certain kinds of supernatural agents (e.g. Atran, 2002; Barrett, 2004; Boyer, 2001). Others have looked at how those beliefs may alter people's behavior, making them act less selfishly (e.g. Bering, 2011; Johnson and Krüger, 2007; Shariff et al., 2016). Religious practices, especially collective rituals, have also been argued to be important in fostering social cohesion and cooperation (e.g. Durkheim, 1995; Whitehouse and Lanman, 2014). Ultimately, many of these scholars suggest that religious beliefs and practices played a crucial role in the emergence of complex societies (e.g. Cronk, 1994; Irons, 2001; Norenzayan et al., 2016; Purzycki et al., 2016; Rappaport, 1999; Shariff et al., 2010; Watts et al., 2015; Wilson, 2003).

As a part of this new evolutionary focus on religion, some researchers have suggested that religious practices, particularly those that place costly demands on the individual, can be signals of commitment to the prosocial tenets of the community (Atran and Norenzayan, 2004; Bulbulia, 2004; Henrich, 2009; Irons, 2001; Sosis and Alcorta, 2003). Drawing on signaling theory (Akerlof, 1970; Bliege Bird and Smith, 2005; Grafen, 1990; Spence, 1973), they suggest that the costs entailed in carrying out religious acts mean that only those who are truly committed will be willing and able to perform them. Costly religious acts can therefore be seen as reliable, honest signals of commitment, allowing religious communities to establish trusting, cooperative relationships.

Applications of the signaling theory of religion tend to evaluate signal honesty, testing the hypothesis that religious signalers are more cooperative. Sosis and Ruffle (2003) found that members of Israeli kibbutzim who attended synagogue more regularly were more cooperative in a common-pool resource game than others, and that they were especially cooperative towards other kibbutz members (Ruffle and Sosis, 2006). Working with Afro-Brazilian Candomblé groups, Soler (2012) found that members who expressed greater commitment to and involvement in the group not only played more generously in a public goods game, but also reported helping other group members more often than less committed members. Xygalatas et al. (2013) gave Hindu festival participants in Mauritius an opportunity to donate money to the temple, and found that those who participated in high ordeal rituals donated significantly more. Across these disparate settings and denominations, each of these projects has found that individuals who expend more time and energy in religious practice are more generous, suggesting that costly religious 
acts can be interpreted as honest signals of commitment and prosociality.

For such acts to truly be seen as "signals," however, researchers need to consider not only the signaler, but also the receiver. While researchers may be convinced that a signal is honest, they also need to establish that signal receivers are able to discern the signal and respond to it (Lachmann et al., 2001; Maynard Smith and Harper, 2003; Rendall et al., 2009). Given the consistency of the literature in asserting that religious signals convey commitment to the beliefs and values of the group, the question arises whether this is indeed the information that the audience perceives. Lab experiments provide some preliminary evidence that signals of religiosity are associated with greater perceived trustworthiness. For example, McCullough et al. (2015) found that American undergraduates viewed individuals as more trustworthy and gave more to them in the trust game if they displayed a Christian religious badge (Ash Wednesday ash or a necklace with a cross), and Hall et al. (2015) found that American Christian undergraduates viewed individuals as more trustworthy if they donated money to religious charities and if they adhered to religious dietary requirements, regardless of whether they were a fellow Christian or a Muslim. In-depth ethnographic studies have not yet been undertaken to see if similar patterns are borne out in the messiness of real life. And, studies have not yet investigated the particular qualities that are imputed from religious signals, beyond general categories of prosociality and trustworthiness. To address these gaps, I draw on data from two South Indian villages to establish the signal content that people discern from the religious action of their peers.

\subsection{Predictions}

Researchers from a variety of disciplines and theoretical backgrounds have forwarded what can generally be termed the "signaling theory of religion," arguing that religious acts can honestly communicate information about the individual's commitment to the religious tenets of the community. Different researchers have emphasized different aspects of the religious system that facilitate this process of communication and discernment. Religious acts often evoke heightened emotional states, which are inherently hard to fake (Alcorta and Sosis, 2005; Frank, 1988). Further, many religious acts entail sizable costs (whether they be physical, psychological, monetary, or opportunity costs), which skeptical individuals are likely unwilling to bear; only those people who truly believe should be willing to carry them out (Sosis and Alcorta, 2003). If the perceived costs of a religious act are more for those who 
are not committed to the belief underlying it than for those who are, then observers can see such acts as credible displays of the belief commitment of those carrying out the religious act (Henrich, 2009). By carrying out such religious acts, individuals demonstrate their willingness to adhere to the social norms and values that are at the core of so many rituals (Rappaport, 1999). For these varied reasons, numerous authors (some grounded in economics, some behavioral ecology, and some cultural evolution) have suggested that costly religious acts can be seen as honestly conveying information about the religious signaler's commitment to the religious and moral precepts of the community. Costly religious actions should therefore help an individual establish a reputation for devotion and for prosociality. Such reputations and the consequent trust it engenders can then help religious signalers establish supportive relationships. Ultimately, these researchers argue that this helps to create cooperative, cohesive communities that can resist skeptical free-riders who are unable to give the costly signals and unwilling to bear the costly requirements often demanded of religious adherents (Iannaccone, 1994; Irons, 2001). This cohesiveness may facilitate cultural group selection, promoting a stable system of beliefs and costly religious practices (Henrich, 2009; Wildman and Sosis, 2011).

Drawing on these varied arguments, we can derive the following predictions to be tested here:

1. People who invest in more and costlier ways in the religious life of the village will be perceived as more devout and more prosocial.

2. Participating in more and costlier ways in the festival for the goddess Māriyamman will lead to increased recognition as devout and prosocial in the days immediately following the festival.

\subsection{Research Setting}

The neighboring villages of "Tenpattị" and "Alakāpuram" (pseudonyms) are located in the South Indian state of Tamil Nadu, near the Vaigai River. Barring a drought, its sporadic waters allow most villagers to spend a few months each year growing rice on small plots of land and the rest engaging in wage labor. The villages are comparable in size, with 164 households in the former and 201 in the latter. Each has a mix of caste groups (jäti) and religious denominations - Hindu, Roman Catholic, Church of South India (CSI, a mainline Protestant denomination), and non-denominational evangelical Christian. The Catholic and Protestant communities are each 
comprised of a single caste, whereas the Hindu residents represent a number of distinct castes (see Table A.6 in the Supplementary Material for a full breakdown). All residents are ethnically and linguistically Tamil.

Religious practice is an intimate part of daily life in these villages. Most Christian households have images of Jesus and Mary adorning their walls, and Hindu households typically have a small area with images of deities for offering a quick prayer and taking tarsan, the mutual viewing of the deity and devotee (Eck, 1981). The Catholic and Protestant churches hold weekly services on Sunday (often lay-led), and a handful of residents read from the Bible early each morning at the Catholic church in Tenpatti. With the many temples and shrines in each village, Hindu residents have more choice in how (and to whom) to direct their devotion. In Tenpatti, many Hindu residents make a quick visit to the temple for the goddess Māriyamman on Tuesdays and Fridays. Each month on the full moon, the local priest ( $p \bar{u} c \bar{a} r i)$ carries out an elaborate worship ( $p \bar{u} j a i)$ at the temple, seeing to the needs of Māriyamman and making offerings (piracātam) to her, which are then shared out among the many attending villagers. In Alakāpuram, Hindus may visit the temples for Vishnu or the guardian deities Ayyanār and Karuppacāmi. About a third of the residents of the two villages worship at a church or temple at least once a week.

Auspicious days and religious holidays entail more involved worship. Christians celebrate Christmas, New Year's Eve (considered a Christian holiday, as it follows the Gregorian, rather than Tamil, calendar), and Easter with new clothes, elaborate meals, games, and formal services. In both villages, the Catholic communities organize an annual festival in which statues of the church's saint are carried in a procession through the village on a palanquin (capparam). In Tenpatți, the Hindu festival for the village goddess Māriyamman each summer is an important event requiring long preparation. Māriyamman is a form of the goddess often found in Tamil villages, sometimes referred to as the goddess of smallpox; she is a powerful, vengeful goddess who protects and defends the village (Beck, 1981; Trawick, 1984; Younger, 1980). The proper carrying out of her festival is seen as ensuring the continued growth and vitality of both the village and its villagers. This growth is represented by the mulaippāri, pots containing bright green sprouts, carried by village women in a procession held during the festival. ${ }^{1}$

\footnotetext{
${ }^{1}$ It is worth noting that Dalit (also known as Untouchable or Scheduled Caste) women
} 
These processions, both for the Catholic and Hindu communities, mark off the domain of the deity and the social boundaries of the village (Jacobsen, 2008; Mines, 2005; Raj and Dempsey, 2002).

Often as a part of these festivals, people voluntarily choose to fulfill ritual vows (nêrttikkatan), acts of devotion carried out in thanks for divine favor (Raj and Harman, 2006). The particular form that the vow takes is the decision of the devotee, and the reason for its enactment is typically kept private. The completion of such vows is typically prefaced by a period of fasting (viratam) to ensure that the vow fulfiller is pure (cuttam) for the act. This includes abstaining from alcohol and meat, remaining abstinent, skipping the midday meal, going without shoes, bathing daily, and avoiding conflict with others. Many residents of Tenpatti carry out vows at the annual festival for Māriyamman, carrying pots of milk ( $p \bar{a} l k u t a m)$ to be poured over the image of the goddess, carrying flaming firepots (akkiniccatti), piercing their bodies with hooks (alaku) or spears $(v \bar{e} l)$, and even suspending themselves from a crane by hooks piercing their backs (the paravai kāvati). Such vows are not limited to festival events; individuals may commit to going on pilgrimage to sites such as the Murugan temple at Palani, the Om Shakthi temple near Chennai, or the Catholic pilgrimage site of Vailankanni. Over the course of a year, most villagers undertake some sort of public ritual action, like fulfilling a vow or traveling to visit a temple or church.

A small number of Hindu residents periodically become possessed, their bodies contorting wildly, beyond their control and consciousness as a deity suddenly "comes" to them (cāmi vantatu). The most conspicuous possession events happen during festivals, typically in one of two ways: first, some people hold official roles (often determined hereditarily) as the god-dancer of a particular deity, and they take on that role during festivals, channeling the god and often its voice; second, the emotional and aural frenzy of the festival can result in a mass of devotees becoming possessed at the same time. ${ }^{2}$

The range of religious action carried out by villagers makes this an ideal setting to test some of the predictions of the signaling theory of religion.

are not permitted to carry mulaippāri, an example of continued caste discrimination.

${ }^{2}$ This form of possession is distinct from possession by pey, malicious trickster spirits (cf. Kapadia, 1995). Such cases, which are quite rare, are seen as undesirable afflictions that must be rectified, often by exorcism. In the terms suggested by Cohen (2008), here I focus on "executive possession" and not "pathogenic possession," such as that by trickster spirits. 
Here, we will see how the nature of villagers' religious practice shapes their reputations. What, exactly, do villagers discern about a person based on her religious practice? Do they actually associate costly ritual acts with devotion and commitment to the tenets of the group? Are the different modes of religious action viewed in the same light, or are they associated with different qualities?

\section{Material \& Methods}

I conducted twenty months of ethnographic fieldwork between October 2011 and August 2013, collecting a variety of data from structured and unstructured interviews, a household census, and a formal survey conducted with adult residents of the two villages. ${ }^{3}$

\subsection{Religious Practice}

Information on villagers' religious practice is divided into three religious modalities: (1) regular worship at a church or temple, (2) public ritual acts, and (3) possession. Villagers reported the regularity of their attendance at church services and temple visitations as part of a household census (conducted between December 2011 and April 2012), which was further corroborated with lists generated by key informants. If a person either self-reported or was named as worshipping at least once a week, they are recorded as worshipping regularly. $82 \%$ of Protestant (CSI) residents attend Sunday services at their church and $72 \%$ of Catholics attend mass. Very few Hindus in Alakāpuram visit temples regularly, while in Tenpatti $44 \%$ of Hindu residents visit the Māriyamman temple each week.

Villagers also reported the public ritual acts that they had carried out over the past year. This could include simply visiting a temple and making an offering, pilgrimages to temples and shrines, vow fulfillment, and activities carried out for major religious holidays like Christmas, Easter, and festivals at nearby regional temples. $80 \%$ of villagers had undertaken at least one public ritual act in the previous year. For the Tenpatți Māriyamman festival, official records kept by festival organizers and video footage of the events were consulted to ensure the most complete possible coverage of the acts carried out as part of this festival. 23\% of adult Hindu residents performed some sort of public ritual act in the 2013 Tenpatți Māriyamman festival.

\footnotetext{
${ }^{3}$ Those interested in accessing the anonymized data should contact the author.
} 
The signaling theory of religion places import on the differential costliness of the acts carried out. To account for this, the measures of each individual's public ritual acts were transformed into new weighted tallies based on a ranking task completed by a random sample of 37 individuals from the two villages (stratified by caste). Each person was given a shuffled pile of 21 cards depicting common religious acts (see Figure A.3 in the Supplementary Materials) and asked to sort them into groups of "low," "medium," and "high" in terms of: difficulty, pain endured, and monetary cost (cards were reshuffled between each sorting). I performed consensus analysis (Romney et al., 1986) on these categorical rankings in UCINET (Borgatti et al., 2002) and found good fit to the consensus models (see Tables A.7 and A.8 in the Supplementary Materials). The results of the consensus analysis form the basis of the weighting system used here. Each act recorded is weighted doubly, assigned first a 1, 2, or 3 (for low, medium, high) for the associated monetary cost, and then another 1,2 , or 3 for the difficulty/pain entailed (the consensus for difficulty and pain were found to be equivalent).

While most people become possessed only during festival events (and often while completing a vow), a smaller number of people become possessed more regularly. 43 Hindu residents $(7 \%)$ were identified by key informants (and corroborated by myself) as often becoming possessed.

\subsection{Reputational Standing}

The reputational metrics are drawn from a survey conducted with the adult residents (age 18+) of Alakāpuram (February 2013) and Tenpatți (April 2013). Of the 809 adult residents, surveys were conducted with 782 of them (97\% overall; $96 \%$ in Alakāpuram and $98 \%$ in Tenpattii). The surveys were administered by graduate students in the Folklore Department at Madurai Kamaraj University, whom I trained in administering the survey. The section of the survey that is relevant here entails eight questions each getting at a different aspect of reputation. Interviewees were asked to free-list all those in the village whom they felt had each quality, and were prompted for each question to think of young and old men and women having the quality. They were asked who in the village was (1) hardworking, (2) particularly generous, (3) good at giving advice, (4) influential, (5) of good character, (6) particularly devout, (7) physically strong, and (8) knowledgeable at carrying out functions and rituals. These qualities are each locally salient and desirable character traits, determined through open-ended interviews and tested with a series of pilot surveys. Overall, interviewees named an average of 18 
people a total of 26 times (meaning, some people were named for various reputational qualities). Correspondingly, each villager was named an average of 21 times by 14 individuals, though there is substantial variance, with many people named only a few times and a few individuals named many times (see Figure A.4 \& Table A.9 in the Supplementary Materials).

In the days immediately following the Tenpatți Māriyamman festival in August 2013, a research assistant and I conducted the survey questions again with a stratified random sample of 50 Tenpatti residents (See Table A.10 in the Supplementary Materials). ${ }^{4}$ In order to compare a person's reputation before and after the festival, the tally of nominations is transformed into the percent a person receives of all of the nominations made in each reputational category.

\subsection{Covariates}

Many other factors beyond religious participation may influence one's reputation and must therefore be accounted for. Basic demographic information (age, gender, caste, years of education) was reported in a household survey. As part of this, I also collected a kinship network of the village, which was analyzed in the population genealogy program Descent (Hagen, 2005) to tally up the number of adult consanguineous kin residing in the village (including adult relatives with $r$ of $\geq 0.125$ ). Finally, holding a position of leadership may influence (and be influenced by) reputation, so a dichotomous variable recording if each villager has ever held a position in the informal village committee or in the local government body (the panchayat) captures this. ${ }^{5}$ Basic descriptive statistics of all relevant variables are included in Table 1.

\section{Results}

\subsection{Prediction 1: Long-Term Religiosity and Reputation}

I first predicted that greater investment in the religious life of the villages would correlate with increased recognition as being devout and prosocial. For

\footnotetext{
${ }^{4}$ Because of the salience of religion and caste in village life, the random selection of 50 respondents was stratified by caste. While I am investigating the change in reputational standing for Hindu festival participants, I am interested in how they are perceived by all villagers, so Christians were included in this random sample.

${ }^{5}$ Other covariates were also considered, but removed due to high colinearity (e.g., an aggregate measure of household property holdings, similar to that used by Waring (2012)) or low explanatory power (e.g., a crossed term of age and education).
} 


\begin{tabular}{|c|c|c|c|c|c|c|}
\hline Variable & $\mathrm{N}$ & Mean \pm SD & Median & Min & Max & \# of Levels \\
\hline Age & 809 & $42.33 \pm 14.98$ & 40 & 18 & 70 & - \\
\hline Gender & 809 & $455 \mathrm{~F}, 354 \mathrm{M}$ & - & - & - & 2 \\
\hline Village & 809 & 438 Ala., 371 Ten. & - & - & - & 2 \\
\hline Caste & 809 & - & - & - & - & 10 \\
\hline Number of Resident Consanguineous Kin & 809 & $2.97 \pm 3.30$ & 2 & 0 & 19 & - \\
\hline Years of Education & 809 & $5.02 \pm 4.98$ & 5 & 0 & 15 & - \\
\hline Ever Committee Member & 809 & 60 Yes, 749 No & - & - & - & 2 \\
\hline Weighted Public Ritual Tally & 809 & $7.06 \pm 5.32$ & 6 & 0 & 37 & - \\
\hline Weighted Māriyamman Festival Tally & 255 & $2.66 \pm 6.01$ & 0 & 0 & 28 & - \\
\hline Regular Worship & 809 & 259 Yes, 550 No & - & - & - & 2 \\
\hline Possession & 809 & 43 Yes, 766 No & - & - & - & 2 \\
\hline
\end{tabular}

Table 1: Descriptive statistics of the model variables

any particular reputational quality, many individuals are not named, while a few individuals are named many times. To account for this skew, I use a hurdle model (Cameron and Trivedi, 2013; Mullahy, 1986), which specifies two components: a binomial model predicting if a response will be zero or greater than zero, and a truncated count component (here, with a negative binomial distribution) predicting the magnitude of positive responses. All analyses are done in $\mathrm{R}$ ( $\mathrm{R}$ Core Team, 2014) using the hurdle function in the pscl package (Jackman, 2014; Zeileis et al., 2008).

I find that the measures of religiosity are often significantly and sizably correlated with the reputational characteristics (Table 2 and Figures A.5 and A.6, full stepwise model results in Tables A.12 to A.19 in the Supplementary Materials).

Regular weekly worship increases the likelihood that a person will be nominated for every reputational quality, except for being strong. For those nominated at least once, regular worship further increases the expected number of nominations for being seen as devout, generous, giving good advice, and having good character.

The weighted tally of public ritual acts is correlated with increased odds of being nominated for every quality, save being seen as influential and having good character. Among those nominated as being devout or giving good advice, a higher weighted tally further increases the expected number of nominations.

Possession increases the odds of being nominated as devout, and decreases the odds of being nominated as hardworking. For those nominated as being devout and having ritual knowledge, getting possessed is correlated with increased nominations. Those nominated as being influential are expected 
to be nominated fewer times if they get possessed.

While regular worship and possession are both dichotomous variables, recall that the weighted tally of public ritual action is not; so, for example, an individual would need a weighted tally of 8 (roughly equivalent to a dramatic ritual act and a simple act) to get the same odds of being nominated for being devout as he/she would get for worshipping regularly.

\begin{tabular}{|c|c|c|c|c|c|c|}
\hline & \multicolumn{3}{|c|}{ Zero } & \multicolumn{3}{|c|}{ Count } \\
\hline & Regular Worship & Possession & Weighted Public Ritual & Regular Worship & Possession & Weighted Public Ritual \\
\hline Hardworking & $0.697^{*}$ & $-1.155^{*}$ & $0.136^{* * *}$ & 0.132 & 0.215 & 0.012 \\
\hline Generous & $0.606^{*}$ & -0.478 & $0.043^{*}$ & $0.482^{*}$ & 0.541 & 0.012 \\
\hline Gives Good Advice & $0.908^{* * *}$ & -0.620 & $0.040^{*}$ & $0.792^{*}$ & 0.196 & $0.051^{*}$ \\
\hline Influential & $0.851^{*}$ & 0.236 & 0.025 & 0.469 & $-2.762^{*}$ & 0.090 \\
\hline Has Good Character & $0.634^{*}$ & 0.526 & 0.025 & $0.470^{*}$ & 0.104 & 0.021 \\
\hline Devout & $0.721^{* *}$ & $2.208^{* *}$ & $0.086^{* * *}$ & $1.409^{* * *}$ & $1.842^{* * *}$ & $0.067^{* * *}$ \\
\hline Strong & 0.359 & 0.090 & $0.064^{* *}$ & -0.167 & 0.534 & -0.008 \\
\hline Has Ritual Knowledge & $0.939^{* * *}$ & 0.278 & $0.054^{* *}$ & 0.611 & $1.279^{* *}$ & 0.042 \\
\hline
\end{tabular}

Table 2: Estimates for the religiosity terms from the hurdle models predicting each reputation tally. Note that each reputation tally is fitted independently; these are separate models with distinct outcome variables. Full model results (with covariates) in supplementary materials.

We can calculate the predicted increases in reputational nominations for each quality, given different degrees of religious involvement (Figure 1). ${ }^{6}$ For example, an older Têvar woman who does no religious practice is predicted to be named twice as hardworking, once as generous, and once as having good character. If she worships regularly and undertakes two dramatic public ritual acts, she is expected to receive one additional nomination each for being generous, giving good advice, having good character, and being knowledgeable about rituals, along with two additional nominations for being hardworking and for being devout. If she gets possessed, she will be named one less time as hardworking and twice more as being devout. If she gets possessed, worships regularly, and undertakes three dramatic public ritual acts, she is expected to be named as devout by upwards of 20 people.

${ }^{6}$ The full specifications used here are: a 42 year-old woman of the Tēvar caste from Tenpattit, with average education (5 years) and average number of resident consanguineous kin (3), who has never been a committee member. 


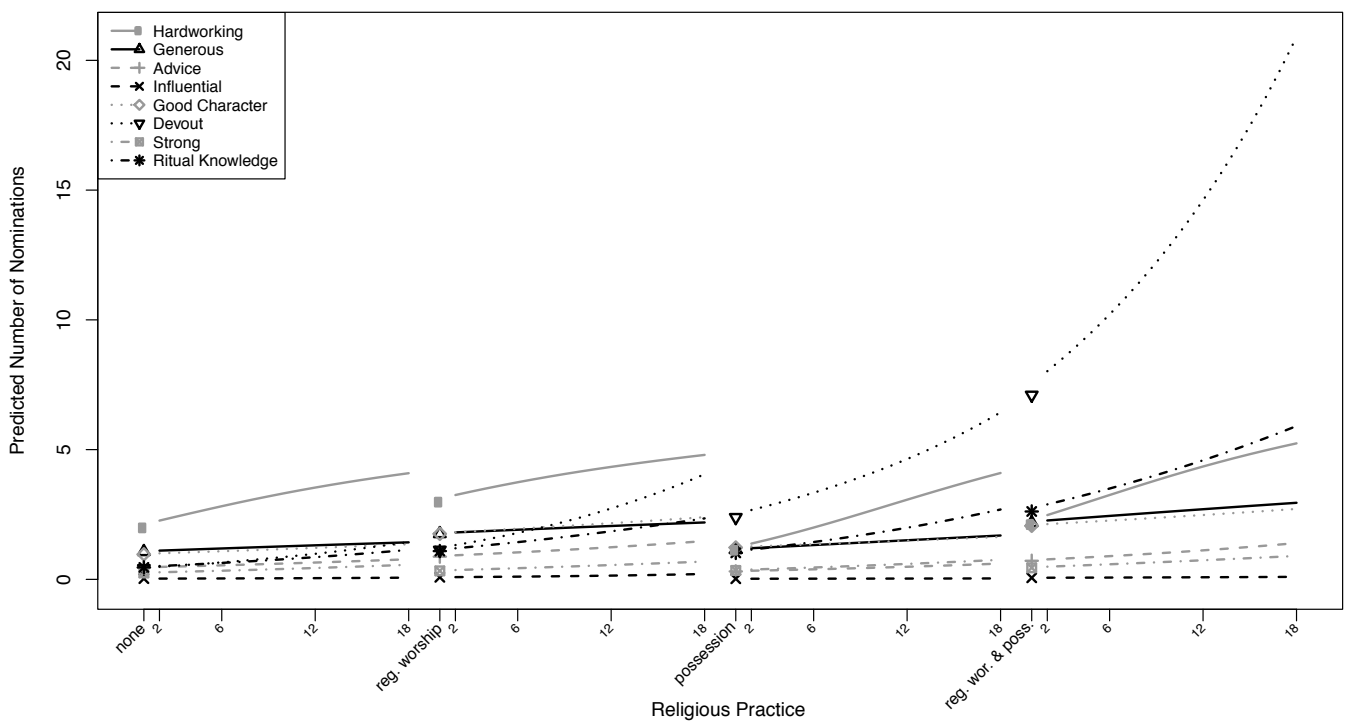

Figure 1: The number of nominations an older Hindu woman of the Têvar caste is predicted to receive for each reputational quality, given different levels of religious involvement. The points (starting from the left) show the predicted number of nominations if (1) she does no religious practice whatsoever, (2) she worships regularly, (3) she gets possessed, (4) she worships regularly and gets possessed. Lines radiating out from these points show the additional predicted nominations if she does additional public ritual practice. Recall that in the weighting system used here, a small ritual act is given a weight of 2 , while a highly difficult, painful, and monetarily costly act is given a weight of 6 . A weighted tally of 12 could be two dramatic acts, or a series of smaller acts.

\subsection{Prediction 2: Short-Term Religiosity and Reputation}

While these models show consistent and significant correlations between religious involvement and various reputational qualities, they cannot be read as causal relationships. The Tenpatți Māriyamman festival provides a unique opportunity to evaluate if there is any direct and immediate impact of religious practice on reputation. Of the 255 adult Hindu residents of Tenpatti, 61 undertook some ritual act in the festival in 2013. The record of each participant's acts is again transformed to a weighted measure that accounts for the greater difficulty and monetary cost of some acts. In the days immediately following the festival, I conducted the same reputational survey with a stratified random sample of 50 Tenpatti residents. The reputational standing of the Hindu residents from before the festival can be compared to 
their standing after the festival, to see if there is any change in recognition in light of festival participation.

\begin{tabular}{lccc}
\hline & Estimate & $\mathrm{R}^{2}$ & Adjusted $\mathrm{R}^{2}$ \\
\hline Hardworking & $0.017^{*}$ & 0.143 & 0.097 \\
Generous & 0.012 & 0.200 & 0.157 \\
Gives Good Advice & 0.017 & 0.082 & 0.032 \\
Influential & -0.011 & 0.049 & -0.002 \\
Has Good Character & 0.017 & 0.175 & 0.131 \\
Devout & $0.028^{\dagger}$ & 0.049 & -0.002 \\
Strong & $0.027^{*}$ & 0.158 & 0.113 \\
Has Ritual Knowledge & 0.015 & 0.176 & 0.132 \\
\hline$* * *$
\end{tabular}

Table 3: Estimates for the weighted tally of festival participation from the linear regression models predicting the normalized percent change in recognition for each reputation quality. Note that each reputational quality is fitted independently; these are separate models. Full model results (with covariates) in Tables A.20 to A.27.

I construct linear regressions for each reputational quality with the change in the percent of nominations received from before to after the festival as the outcome variable. ${ }^{7}$ I include the same covariates that are used to test Prediction 1. The regressions show that the weighted tally of festival participation is significantly positively correlated with an increase in recognition as being physically strong, having a good work ethic, and being devout (Table 3). A person who undertakes two dramatic acts at the festival is predicted to receive an additional $0.3 \%$ of the total number of nominations for being physically strong (which translates to about one additional nomination), as well as for being hardworking (the equivalent of about two additional nominations). The change in a person's reputation for being devout shows the greatest increase with greater festival involvement (Figure 2). ${ }^{8}$

\footnotetext{
${ }^{7}$ I use the percent of all nominations received rather than the raw number of nominations or the percent of people nominating someone, because the probability of being nominated in the two surveys differs (see Table A.10).

${ }^{8}$ Even though it has a large coefficient for the weighted tally of festival participation, it is worth noting that the $\mathrm{R}^{2}$ value for the full model predicting change in nominations for being devout is the lowest of all of the models. This is largely due to the fact that the other covariates are almost all non-significant (see Table A.25 in the Supplementary Materials). The model with the lowest AIC is a model including only the weighted festival tally.
} 


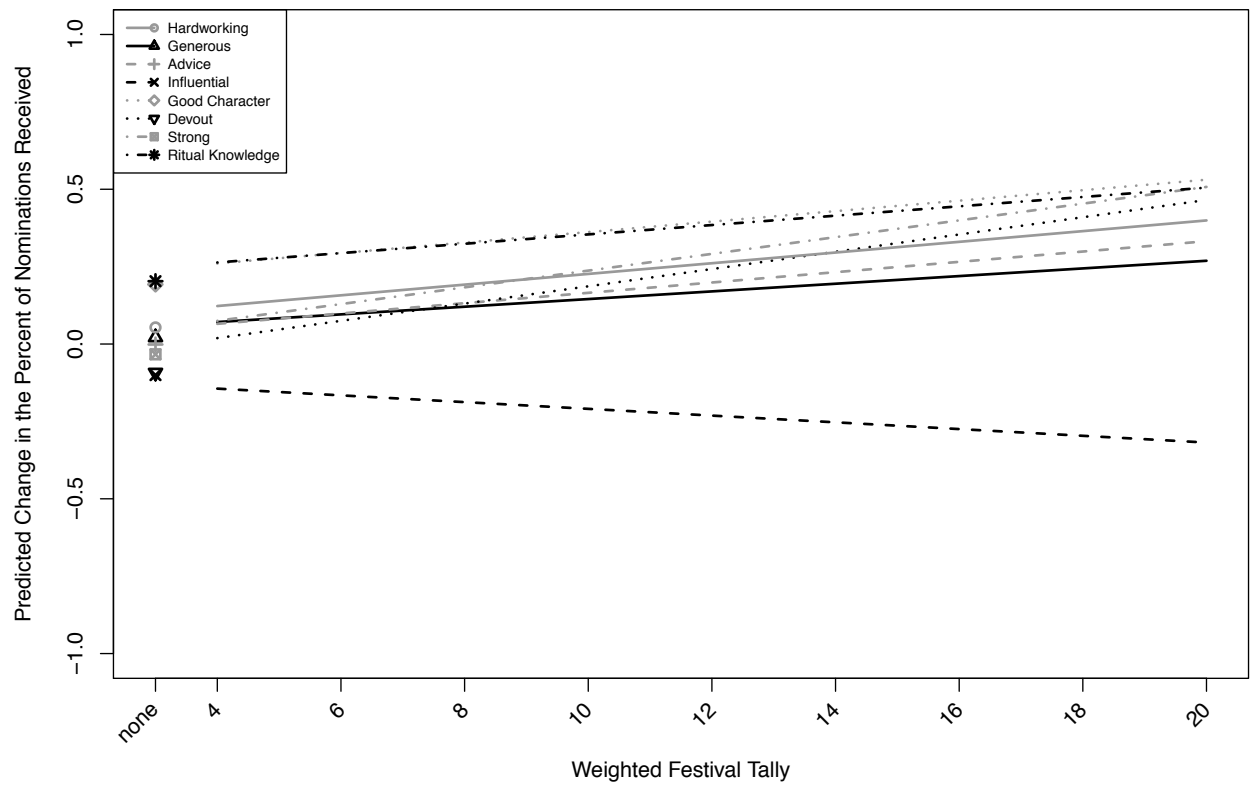

Figure 2: The change in the percent of nominations an older Hindu woman of the Tēvar caste is predicted to receive for each reputational quality, given different levels of participation in the Tenpațti Māriyamman festival.

\subsection{Prior Knowledge of Religiosity}

These relatively weak short-term relationships are likely due to the fact that people who participate actively in the festival also undertake other religious acts over the course of the year. ${ }^{9}$ There is a strong correlation between the weighted tally of Măriyamman festival participation and the long-term weighted tally of religious acts (the Pearson's product-moment correlation is $0.29, p<0.0001$ ). Those who worship regularly similarly have a higher mean festival weighted tally (those who do not worship regularly have a mean of 1.06 , whereas those who do have a mean weighted tally of $3.10, t=-3.86, p=0.0002)$. The festival acts, then, are one among many observable demonstrations of religiosity. The dramatic acts undertaken at the Māriyamman festival are not viewed in isolation; rather, they are one

\footnotetext{
${ }^{9}$ Only five of the 61 festival participants are recorded as having done no other public ritual acts in the previous year, and this is almost certainly due to the inability of the household survey to capture all religious practice.
} 
single new data point added to a long list of prior observations on an individual. Consequently, these acts should result in only relatively minor shifts in people's perceptions. Put another way, the villagers of Tenpatți likely have quite good priors about their peers and so need to do only relatively minor updating (Bernardo and Smith, 1994; Laplace, 1986; Sutton and Barto, 1998; Tenenbaum et al., 2011).

\begin{tabular}{lccccccc}
\hline & \multicolumn{3}{c}{ Under $\mathbf{4 0}(\mathbf{N}=\mathbf{1 0 3})$} & & \multicolumn{3}{c}{$\mathbf{4 0}$ and Over $(\mathbf{N}=\mathbf{1 4 9})$} \\
\cline { 2 - 3 } \cline { 6 - 7 } & Estimate & $\mathrm{R}^{2}$ & Adjusted $\mathrm{R}^{2}$ & & Estimate & $\mathrm{R}^{2}$ & Adjusted $\mathrm{R}^{2}$ \\
\hline Hardworking & $0.021^{*}$ & 0.319 & 0.236 & & 0.013 & 0.098 & 0.026 \\
Generous & 0.013 & 0.281 & 0.194 & & 0.011 & 0.198 & 0.133 \\
Gives Good Advice & $0.023^{*}$ & 0.166 & 0.065 & & 0.005 & 0.088 & 0.015 \\
Influential & -0.004 & 0.205 & 0.109 & & -0.033 & 0.090 & 0.017 \\
Has Good Character & $0.028^{*}$ & 0.200 & 0.103 & & 0.003 & 0.258 & 0.198 \\
Devout & $0.045^{\dagger}$ & 0.082 & -0.030 & & 0.007 & 0.152 & 0.084 \\
Strong & $0.049^{* *}$ & 0.141 & 0.038 & & 0.007 & 0.242 & 0.181 \\
Has Ritual Knowledge & -0.003 & 0.124 & 0.018 & & 0.040 & 0.240 & 0.179 \\
\hline
\end{tabular}

${ }^{* * *} p<0.001,{ }^{* *} p<0.01,{ }^{*} p<0.05,{ }^{\dagger} p<0.10$

Table 4: Estimates for the weighted tally of festival participation from the linear regression models predicting the normalized percent change in recognition for each reputation quality. Note that each reputational quality is fitted independently; these are separate models. Divided into those over and under 40. Full model results (with covariates) in Tables A.28 and A.29.

The role of prior knowledge in shaping the reputational impact of the Māriyamman festival acts can be investigated further. Villagers should have particularly good prior knowledge of older individuals, as they will simply have had more time to observe them. Similarly, villagers should know relatively less of younger individuals, who are still establishing themselves in the village. Consequently, Māriyamman festival acts should result in more substantial updating for younger people than older, as the information value is greater. As a test of this, I divide the sample of the 255 adult Hindu residents of Tenpatti into those under the age of forty and those forty or older, roughly dividing the population into two. ${ }^{10}$ I then run the same lin-

\footnotetext{
${ }^{10}$ There is no significant difference in the level of festival participation between the two age groups for those who partake in the festival. The mean weighted festival tally for those under forty is 8.25 , while it is 8 for those over forty $(t=-0.21, p=0.8312)$. However, a greater percentage of younger individuals partake in the festival (27\% of those under forty versus $19 \%$ of those over forty). The greater rate of participation of younger individuals
} 
ear regression models (removing the age variables), and compare the results for the younger and older populations. As the results in Table 4 show, the weighted tally of festival participation only has a significant effect on reputational change for the Hindu residents under forty; festival participation does not significantly alter any reputational quality for those over forty. For younger individuals, greater and costlier festival participation significantly increases the percent of nominations a person receives for being hardworking, giving good advice, having good character, and being physically strong. While the effect of costlier festival participation is still small, it is relatively greater for those individuals about whom villagers have less information, and so for whom these acts are more informative.

\section{Discussion}

These results suggest that the villagers of Tenpatṭi and Alakāpuram are indeed using the religious practice of their peers to discern something about their underlying character and beliefs. The long-term association between an individual's religious practice over the course of a year and her reputational standing suggests that villagers are attuned to those behaviors and shape their perception of a person in light of them. The more immediate shifts in reputation seen in the aftermath of the Māriyamman festival also suggest that villagers are continually evaluating one another and revising their opinions in response to the information encoded in these new signals.

That villagers are using a person's religious practice to impute something about their character and intentions is suggested by more than just these data: villagers themselves say as much. Tamils perceive themselves as having a relatively permanent nature (kunam, also sometimes translated as character), alterable somewhat through concerted effort (karmam) (Daniel, 1984). The qualities associated with "good character" (nalla kunam) largely revolve around the articulation of the individual within the larger social group: a "good person" (nallavar) should be generous, trustworthy, honorable and modest, avoiding selfish advancement at the cost of others (Mines, 1994). One's kunam is something that must be constantly worked upon, both by striving to restrain basal desires and resist vices and also by cultivating one's

may reflect a greater perceived benefit for younger individuals, perhaps suggesting that sexual selection plays a role here. 
more virtuous qualities (Pandian, 2009; Pandian and Ali, 2010). This striving towards goodness often happens in the religious sphere, as people make vows in the hopes of bettering themselves and their position, thereby making religious practice especially informative of a person's kunam. Fulfilling a vow is taken as evidence of the divine's intervention in one's lot and the successful overcoming of some difficulty. Villagers are therefore close observers of these acts, looking for even minute hints - such as how slowly a person strides across the bed of hot coals or how quickly the wound left by a spear heals - that can be revealing of a person's kunam and divine favor (or disfavor). As Kapadia's (1995, pg. 143) interlocutors described it, "genuine devotion shines through."

\subsection{The Signal Value of Religious Practice}

What is it, exactly, that villagers are discerning about a person's kunam from her religious practice? The data presented here suggest that villagers most clearly associate bhakthi, the ardent love of the divine, with religious practice. Worshipping regularly, undertaking more and costlier public ritual acts, and getting possessed are all correlated with increased nominations for being devout. In the short term, undertaking more dramatic acts in the Māriyamman festival also leads to an immediate, if small, increase in recognition for being seen as devout. The related quality of being knowledgeable in ritual form is also strongly associated with both regular worship and ritual action.

While it is perhaps not surprising that those who perform more religious action are seen as more religious, it is somewhat more so that other character traits are also imputed into those who invest more in the religious life of the village. The particular traits that are ascribed to a person depend on the religious modality being undertaken. A reputation for physical strength, for example, is exclusively associated with greater and costlier (and more physically demanding) public ritual acts, both in the short and long term. Regular worship and public ritual acts are both correlated with increasing recognition for having a good work ethic and for giving good advice. Regular worship is more strongly associated with a reputation for having good character and being generous. Only a reputation for being influential is essentially uninfluenced by religious practice (while there is a significant correlation with regular worship, its effect size is extremely minimal).

Compared to the other two types of religious practice, possession is something of an anomaly. Beyond marking someone as devout, it has a negligible 
or negative correlation with other reputational qualities. This seems to imply that villagers are gleaning less information from a person's possession. This may largely be due to the fact that when someone is possessed, the relevant signaler is the deity, not the person acting as a temporary vessel for that deity (Cohen and Barrett, 2008a,b). While the opening up of a person to possession reveals her to be an ardent believer with great devotion, all other insight to be gained from possession is presumably ascribed to another agent entirely. Given this, possession is not likely to be a useful signal of underlying quality. Much anthropological work on possession highlights how it can provide an important opportunity for making claims to moral worth, especially for those who may otherwise not be able to voice such sentiments (e.g. Lambek, 1981; Lewis, 1971; Masquelier, 2001; Obeyesekere, 1981). In keeping with this, possession in Tamil Nadu is generally associated with low caste, low class, women (Kapadia, 1995). Despite controlling for these factors in the analyses presented above, the strong cultural association between possession and socially marginal individuals may further dampen any potential for a positive association between possession and esteemed reputational qualities.

The results presented here draw particular attention to the signal value of regular worship. While dramatic ritual acts may draw the biggest crowds (whether of local onlookers or of research scientists), it is often the subtle act of regular worship that draws the biggest reputational benefits. Regular worship is more strongly associated with many of the reputational qualities than the weighted tally of ritual acts, particularly the qualities of generosity and good character, the two most clearly prosocial qualities under study here. The generally stronger effect of regular worship can be attributed to the accumulation of many months and even years worth of demonstrations of religious commitment. This consistent reminder of a person's religiosity appears to offer more convincing evidence of a person's prosociality than sporadic, often one-off dramatic ritual acts.

In sum, people who worship regularly and undertake greater and costlier ritual acts are not only seen as more devout, but are also associated with a suite of traits that are prosocial, other-focused, and morally grounded. They are more likely to be seen as having a good work ethic, giving good advice, being generous, and having good character. Each of these qualities is certainly an aspect of the good kunam that villagers are striving toward. All entail a deep understanding and acceptance of the community's moral dicta, a commitment to helping others, and a more general focus on the needs and 
desires of others. ${ }^{11}$ Importantly, this suite of characteristics does not always appear in one person. In fact, these traits are often not highly correlated with each other (see Table A.11 in the Supplementary Materials). More tellingly, most of the reputational qualities are particularly weakly correlated with the reputation for being devout. This suggests that a reputation for being devout is not mediating all of the other associations; rather, people who worship regularly and undertake greater and costlier religious acts are seen as being deeply committed to their deities, and additionally (but separately from that) as having some combination of these other prosocial qualities.

The results reported here extend experimental work showing that religious individuals are often perceived as more trustworthy (Hall et al., 2015; McCullough et al., 2015; Purzycki and Arakchaa, 2013; Ruffle and Sosis, 2010; Tan and Vogel, 2008; Widman et al., 2009). Here, I have drawn on quantitative ethnographic evidence to show that reputational evaluations of one's peers are shaped, in part, by the religious practice they undertake. Importantly, these evaluations are being made not only be people of one's own religious community, but by all villagers, whether Hindu, Catholic, Protestant, or atheist (cf. Hall et al., 2015). In conjunction with the work directly measuring the cooperativeness of religious individuals (Power, 2015; Ruffle and Sosis, 2006; Soler, 2012; Sosis and Ruffle, 2003; Xygalatas et al., 2013), these findings suggest that religious practice can be an honest signal conveying the religious commitment and prosocial intent of the signaler.

${ }^{11}$ The contrast between advice-giving and influence is informative. While being influential and giving good advice both entail guiding and directing people, commanding attention, and being deferred to, they are distinct in one notable way. Imparting sound advice requires knowledge of and adherence to the moral values of the group, as well impartially and the ability to rise above the petty factionalism of village politics. Being influential, in contrast, captures a type of political dominance and coalitional calculation that can run contrary to such values. Elected officials and local leaders (periyavarkal, "big men"), for example, are often seen as cunning political players looking for opportunities to advance themselves and their constituents (and, sometimes, to fill their pockets with bribes and graft). Appropriately, then, people who worship and perform rituals that inherently entail an acknowledgement and acceptance of the moral dicta of the religion and the group (Rappaport, 1994, 1999) are more likely to be seen as good advice-givers, but not as influential. 


\subsection{Multimodal and Multiplex Signals}

The signaling theory of religion generally contends that individuals signal their adherence to cooperative norms and their commitment to the tenets of the religious community through costly and therefore honest ritual acts (Alcorta and Sosis, 2005; Atran and Norenzayan, 2004; Bulbulia, 2004; Bulbulia and Sosis, 2011; Henrich, 2009; Irons, 2001; Sosis and Alcorta, 2003). With this study, I have found clear evidence in support of these claims. However, this study also reveals that this is a much more complex signaling system than is often portrayed. Rather than a single clear signal of religious commitment, the villagers of Tenpatti and Alakāpuram are attending to multiple modes of religiosity, which are defined by distinct sets of costs, and which simultaneously convey multiple messages of signaler quality and intent.

The three types of religious signals reported here are not equivalent displays, as each entails a unique form of action and each places distinct burdens on the individual. Possession is typically a spontaneous, frenetic, and shortlived display of fervent devotion. Public rituals comprise a wide range of acts, from making a small offering at a nearby temple, to carrying a scalding firepot in a procession. More dramatic public ritual acts can require a long period of fasting and abstention, entail nontrivial monetary costs, involve enduring serious pain, and risk bodily harm. In comparison, worshipping at a church or temple may seem to be a rather trivial commitment of time, but the cumulative investment over the course of months and years is substantial.

When evaluating these forms of religious display, villagers use distinct metrics and take into account the varying contexts in which these acts take place. While possession is generally seen as a visceral demonstration of devotion, some people (mainly Christians) doubt that possession actually occurs, while others who do believe may be unsure of who, exactly, is doing the possessing. People attempt to assess the veracity of possession largely by attending to cues of emotional intensity (cf. Frank, 1988). Public ritual acts are typically evaluated not by their emotional correlates, but by the myriad costs entailed in carrying them out (monetary, physical, opportunity), particularly the long period of fasting that precedes the ritual. However, such costs are not seen as necessarily guaranteeing the character of the actor. Villagers recognize that dramatic acts can help to build one's reputation and renown (perumai); if rituals are seen as being done in order to get that return, those same acts will be viewed as evidence not of growing perumai, but of tarperumai - self-pride and boastfulness (cf. Barclay and Willer, 2007; Bliege Bird and Power, 2015; Lee, 1969). Regular worship does not entail the fervor of 
possession or the costs and risks of dramatic rituals. It does, though, entail a consistent investment of time, during which attendees can be easily observed by their peers. The fact that regular worship is not eye-catching and crowddrawing (as possession and ritual are) actually serves as its guarantor. That people continue to worship week upon month upon year, despite its relative subtlety as a signal, makes regular worship a seemingly unassailable marker of devotion (and, as the results presented here show, prosociality). ${ }^{12}$ It is not only the explicit costs entailed in carrying out a signal that serve as markers of honesty; a wide range of factors is brought to bear when evaluating any potential signal.

\begin{tabular}{|c|c|c|c|c|c|c|c|}
\hline & \multicolumn{2}{|c|}{ Tenpatti } & \multicolumn{4}{|c|}{ Alakāpuram } & \multirow{2}{*}{ Total } \\
\hline & Hindu & Catholic & Hindu & Catholic & Protestant & Evangelical & \\
\hline None & 42 & 19 & 74 & 0 & 9 & 0 & 144 \\
\hline Worship Only & 8 & 9 & - & 1 & 1 & 0 & 19 \\
\hline Possession Only & 0 & - & 0 & - & - & - & 0 \\
\hline Public Ritual Only & 97 & 12 & 269 & 4 & 2 & 0 & 384 \\
\hline Worship \& Public Ritual & 82 & 76 & 0 & 5 & 48 & 8 & 219 \\
\hline Possession \& Public Ritual & 5 & 0 & 17 & - & - & - & 22 \\
\hline All & 21 & - & - & - & - & - & 21 \\
\hline
\end{tabular}

Table 5: Number of residents undertaking each combination of religious modalities, by village and religious denomination. There is no regular worship at a temple in Alakāpuram. Christians in these villages do not become possessed.

While I have largely contrasted the various types of religiosity here, it is important to note that they are often done in conjunction with one another. Many people (32\% of villagers) perform multiple modes of religious action (Table 5). These actors can be seen as giving "multicomponent" or "multimodal" signals (Higham and Hebets, 2013; Partan and Marler, 1999, 2005). By combining signals across a variety of channels and sensory modalities, signalers can increase message fidelity and robustness to ensure that the signal is reliably conveyed (Ay et al., 2007; Rowe, 1999). The villagers' skepticism surrounding some people's motivations for carrying out dramatic, flashy ritual acts, for example, can be allayed when other religious action (such as regular worship) is also carried out, reinforcing each individual signal.

Each of these religious modalities is also multiplex, conveying information

\footnotetext{
${ }^{12}$ Tellingly, the person to receive by far the most nominations for being devout is the woman who gets up before most people are awake each morning to clean the Māriyamman temple. 179 people named her as being devout, a full $50 \%$ of the villagers of Tenpatti. The next most nominated person in Tenpatți received exactly 100 fewer nominations.
} 
about numerous character traits. Religious practice is not simply revealing of a singular quality (say, devotion), but rather is used to glean insights into multiple aspects of a person's character (their devotion, as well as their work ethic, generosity, etc.). And, each particular religious mode is associated with a distinct set of underlying qualities. Villagers are discerning different information from a person's dramatic public ritual act than from her regular worship, for example. Furthermore, as individuals may be attending to different aspects of that multiplex signal, we can see them as "pluripotent" (Hebets et al., 2016). The unmarried woman might be most impressed by a spear-taker's feat of strength, for example, while her parents may simultaneously be happily noting his clear dedication to the goddess and the village. When attempting to discern something about the kunam of their peers, then, villagers draw upon a complex set of signals - some dramatic, some subtlethat collectively convey information across a wide set of character traits.

Of course, these multimodal and multiplex signals are being carried out not just across the year for which I have observational data, but for much longer periods of time. The residents of Tenpatti and Alakāpuram know each other well. Across the years, they will have witnessed innumerable signals - religious or otherwise - with which to formulate a rich assessment of one another. Not surprisingly, then, the relationships reported here are stronger for the long-term aggregate measures of religious participation than for the isolated acts carried out in the Māriyamman festival. The measure of year-long religious practice gives a better approximation of the cumulative information villagers have to draw upon when forming their opinion of their peers. The fact that more weight appears to be given to the festival acts of younger compared to older people provides further evidence that each signal is viewed not in isolation, but in conjunction with prior beliefs formed from the observation of past signals. For those about whom villagers already have ample information, further religious signals will do little to alter their perceptions; for those who are relatively less well known, each additional signal can be more informative and lead to more substantial updating of perceptions.

This image of a more complex religious signaling system than might typically be presented in the signaling theory of religion (and characterizations of it) is in keeping with recent refinements and extensions of signaling theory in behavioral ecology (e.g. Hebets and Papaj, 2005; McGregor, 2005; Searcy and Nowicki, 2005). Such advancements demonstrate that while the signaling theory of religion is often represented as being focused exclusively 
on costly, extreme acts, it certainly is not and need not be limited to this. Related models, such as Henrich's (2009) "credibility enhancing displays" accord well with this broader signaling framework (and additionally highlight the importance of learning biases and cultural evolution to religious systems). This attempt and other such efforts (e.g. Atran and Henrich, 2010; Norenzayan et al., 2016) to integrate and better specify the broad field of evolutionary explanations of religion are valuable efforts to reconcile findings from cognitive science, evolutionary psychology, human behavioral ecology, cultural evolution, and economics to arrive at a more complete understanding of religion. The findings presented here add new empirical fodder to this rich and dynamic field.

\section{Conclusions}

People bring a large amount of information to bear when discerning someone's character. This includes not only their religious practice, but also other important aspects of their day-to-day lives and interactions. There too, research suggests that people draw upon multiple inputs to determine multiple aspects of a person's reputation and social status (von Rueden et al., 2008). Here, I have focused on one small corner of people's actions and established what villagers perceive from them.

The villagers of Tenpatti and Alakāpuram appear to be using the religious practice of their peers to discern something about their religious commitment and prosocial intent. Different types of religious action - each with its own set of costs and risks, and its own level of observability - are associated with distinct constellations of reputational qualities. It is not only the dramatic acts of firewalking or possession that are attended to, but also the relatively more subtle act of regular worship. In fact, the results presented here show that regular worship is often associated with greater recognition. Had this study focused exclusively on the obvious, eye-catching acts with their clear costs, the religious signaling system would have been misconstrued. This highlights the value of observing (as the villagers do) the full signaling system, noting the additive, multimodal signals and their multiplex messages.

\section{Acknowledgements}

The author is grateful for the patience and kindness of the villagers of Tenpatti and Alakāpuram, the support of faculty and students from the Folklore Department at Madurai Kamaraj University, and the comments and suggestions of Rebecca Bliege 
Bird, Richard Sosis, James Holland Jones, Tanya Luhrmann, Sharika Thiranagama, Mirta Galesic, Michael Price, Elspeth Ready, and Jessie Barker. This research was funded by a National Science Foundation Doctoral Dissertation Improvement Grant (BCS-1121326), a Fulbright-Nehru Student Researcher Award, the Stanford Center for South Asia, and Stanford University. 


\section{Bibliography}

Akerlof, G. A., 1970. The market for "lemons": quality uncertainty and the market mechanism. The Quarterly Journal of Economics 84 (3), 488-500.

Alcorta, C. S., Sosis, R., 2005. Ritual, emotion, and sacred symbols. Human Nature 16 (4), 323-359.

Atran, S., 2002. In gods we trust: the evolutionary landscape of religion. Oxford University Press, Oxford; New York.

Atran, S., Norenzayan, A., 2004. Religion's evolutionary landscape: Counterintuition, commitment, compassion, communion. Behavioral and Brain Sciences 27, 713-770.

Atran, S., Henrich, J. 2010. The evolution of religion: how cognitive by-products, adaptive learning heuristics, ritual displays, and group competition generate deep commitments to prosocial religions. Biological Theory 5 (1), 18-30.

Ay, N., Flack, J., Krakauer, D. C., 2007. Robustness and complexity co-constructed in multimodal signalling networks. Philosophical Transactions of the Royal Society B: Biological Sciences 362 (1479), 441-447.

Barclay, P., Willer, R., 2007. Partner choice creates competitive altruism in humans. Proceedings of the Royal Society B: Biological Sciences 274 (1610), 749-753.

Barrett, J. L., 2004. Why would anyone believe in God? AltaMira Press, Lanham, MD.

Beck, B. E. F., 1981. The goddess and the demon: a local South Indian festival and its wider context. Collection Puruṣārtha: Centre d'études de l'Inde et de l'Asie du Sud 5, 83-136.

Bering, J. M. The belief instinct: the psychology of souls, destiny, and the meaning of life. W. W. Norton, New York.

Bernardo, J. M., Smith, A. F. M., 1994. Bayesian theory. Wiley, New York.

Bliege Bird, R., Power, E. A., 2015. Prosocial signaling and cooperation among Martu hunters. Evolution and Human Behavior 36 (5), 389-397.

Bliege Bird, R., Smith, E. A., 2005. Signaling theory, strategic interaction, and symbolic capital. Current Anthropology 46 (2), 221-248.

Borgatti, S. P., Everett, M. G., Freeman, L. C., 2002. UCINET for Windows: Software for social network analysis.

Boyer, P., 2001. Religion explained: the evolutionary origins of religious thought. Basic Books, New York. 
Bulbulia, J., 2004. Religious costs as adaptations that signal altruistic intention. Evolution and Cognition 10 (1), 19-38.

Bulbulia, J., Sosis, R., 2011. Signalling theory and the evolution of religious cooperation. Religion 41 (3), 363-388.

Cameron, A. C., Trivedi, P. K., 2013. Regression analysis of count data, 2nd Edition. Cambridge University Press, New York, NY.

Cohen, E., 2008. What is spirit possession? Defining, comparing, and explaining two possession forms. Ethnos 73 (1), 101-126.

Cohen, E., Barrett, J. 2008a. When minds migrate: conceptualizing spirit possession. Journal of Cognition and Culture 8 (1), 23-48.

Cohen, E., Barrett, J. 2008b. Conceptualizing spirit possession: ethnographic and experimental evidence. Ethos 36 (2), 246-267.

Cronk, L., 1994. Evolutionary theories of morality and the manipulative use of signals. Zygon 29 (1), 81-101.

Daniel, E. V., 1984. Fluid signs: being a person the Tamil way. University of California Press, Berkeley, CA.

Durkheim, E., 1995. The elementary forms of religious life. Free Press, New York.

Eck, D. L., 1981. Darśan, seeing the divine image in India. Anima Books, Chambersburg, PA.

Frank, R. H., 1988. Passions within reason: the strategic role of the emotions, 1st Edition. Norton, New York.

Grafen, A., 1990. Biological signals as handicaps. Journal of Theoretical Biology 144 (4), $517-546$.

Hagen, E. H., 2005. Descent. Version 0.2.0.2.

Hall, D. L., Cohen, A. B., Meyer, K. K., Varley, A. H., Brewer, G. A., 2015. Costly signaling increases trust, even across religious affiliations. Psychological Science 26 (9), 1368-1376.

Hebets, E. A., Papaj, D. R. 2005. Complex signal function: developing a framework of testable hypotheses. Behavioral Ecology and Sociobiology 57 (3), 197-214.

Hebets, E. A., Barron, A. B., Balakrishnan, C. N., Hauber, M. E., Mason, P. H., Hoke, K. L., 2016. A systems approach to animal communication. Proceedings of the Royal Society of London B: Biological Sciences 283 (1826), 20152889. 
Henrich, J., 2009. The evolution of costly displays, cooperation and religion: credibility enhancing displays and their implications for cultural evolution. Evolution and Human Behavior 30 (4), 244-260.

Higham, J. P., Hebets, E. A., 2013. An introduction to multimodal communication. Behavioral Ecology and Sociobiology 67 (9), 1381-1388.

Iannaccone, L. R., 1994. Why strict churches are strong. The American Journal of Sociology $99(5), 1180-1211$.

Irons, W., 2001. Why are humans religious? An inquiry into the evolutionary origins of religion. Currents in Theology and Mission 28 (3-4), 357-368.

Jackman, S., 2014. pscl: classes and methods for R developed in the Political Science Computational Laboratory, Stanford University.

Jacobsen, K. A. (Ed.), 2008. South Asian religions on display: religious processions in South Asia and in the diaspora. Routledge South Asian religion series. Routledge, London; New York.

Johnson, D. D. P., Krüger, O., 2007. The good of wrath: supernatural punishment and the evolution of cooperation. Political Theology 5 (2), 159.

Kapadia, K., 1995. Siva and her sisters: gender caste and class in rural South India. Westview Press, Boulder, CO.

Lachmann, M., Számadó, S., Bergstrom, C. T., 2001. Cost and conflict in animal signals and human language. Proceedings of the National Academy of Sciences of the United States of America 98 (23), 13189-13194.

Lambek, M., 1981. Human spirits: a cultural account of trance in Mayotte. Cambridge University Press, Cambridge; New York.

Laplace, P. S., 1986. Memoir on the probability of the causes of events. Statistical Science 1 (3), 364-378.

Lee, R. B., 1969. Eating Christmas in the Kalahari. Natural History LXXVIII (10), 60-63.

Lewis, I. M., 1971. Ecstatic religion; an anthropological study of spirit possession and shamanism. Penguin Books, Harmondsworth, UK.

Masquelier, A. M., 2001. Prayer has spoiled everything possession, power, and identity in an Islamic town of Niger. Duke University Press, Durham, N.C.

Maynard Smith, J., Harper, D., 2003. Animal signals. Oxford series in ecology and evolution. Oxford University Press, Oxford; New York. 
McCullough, M. E., Swartwout, P., Shaver, J. H., Carter, E. C., Sosis, R., 2015. Christian religious badges instill trust in Christian and non-Christian perceivers. Psychology of Religion and Spirituality.

McGregor, P. K. 2005. Animal communication networks. Cambridge University Press, New York.

Mines, D. P., 2005. Fierce gods: inequality, ritual, and the politics of dignity in a South Indian village. Indiana University Press, Bloomington, IN.

Mines, M., 1994. Public faces, private voices. University of California Press, Berkeley, CA.

Mullahy, J., 1986. Specification and testing of some modified count data models. Journal of Econometrics 33 (3), 341-365.

Norenzayan, A., Shariff, A. F., Gervais, W. M., Willard, A. K., McNamara, R. A., Slingerland, E., Henrich, J., 2016. The cultural evolution of prosocial religions. Behavioral and Brain Sciences 39, e1 (19 pages).

Obeyesekere, G., 1981. Medusa's hair: an essay on personal symbols and religious experience. University of Chicago Press, Chicago, IL.

Pandian, A., 2009. Crooked Stalks: cultivating virtue in South India. Duke University Press, Durham, NC.

Pandian, A., Ali, D. (Eds.), 2010. Ethical life in South Asia. Indiana University Press, Bloomington, IN.

Partan, S., Marler, P., 1999. Communication goes multimodal. Science 283 (5406), 1272 1273.

Partan, S., Marler, P., 2005. Issues in the classification of multimodal communication signals. The American Naturalist 166 (2), 231-245.

Power, E. A., 2015. Building bigness: Religious practice and social support in rural South India. Doctoral Dissertation, Stanford University, Stanford, CA.

Purzycki, B. G., Apicella, C., Atkinson, Q. D., Cohen, E., McNamara, R. A., Willard, A. K., Xygalatas, D., Norenzayan, A., Henrich, J., 2016. Moralistic gods, supernatural punishment and the expansion of human sociality. Nature 530 (7590), 327-330.

Purzycki, B. G., Arakchaa, T., 2013. Ritual behavior and trust in the Tyva Republic. Current Anthropology 54 (3), 381-388.

R Core Team, 2014. R: A language and environment for statistical computing.

Raj, S. J., Dempsey, C. G. (Eds.), 2002. Popular Christianity in India: riting between the lines. State University of New York Press, Albany, NY. 
Raj, S. J., Harman, W. P. (Eds.), 2006. Dealing with deities: the ritual vow in South Asia. State University of New York Press, Albany, NY.

Rappaport, R. A., 1994. On the evolution of morality and religion: a response to Lee Cronk. Zygon 29 (3), 331-349.

Rappaport, R. A., 1999. Ritual and religion in the making of humanity. Cambridge University Press, Cambridge, UK; New York.

Rendall, D., Owren, M. J., Ryan, M. J., 2009. What do animal signals mean? Animal Behaviour 78 (2), 233-240.

Romney, A. K., Weller, S. C., Batchelder, W. H., 1986. Culture as consensus: a theory of culture and informant accuracy. American Anthropologist 88 (2), 313-338.

Rowe, C., 1999. One signal or two? Science 284 (5415), 741-741.

Ruffle, B. J., Sosis, R., 2006. Cooperation and the in-group-out-group bias: A field test on Israeli kibbutz members and city residents. Journal of Economic Behavior \& Organization 60 (2), 147-163.

Ruffle, B. J., Sosis, R. H., 2010. Do religious contexts elicit more trust and altruism? An experiment on Facebook. SSRN eLibrary.

Searcy, W. A., Nowicki, S. 2005. The evolution of animal communication: reliability and deception in signaling systems. Princeton University Press, Princeton, NJ.

Shariff, A. F., Willard, A. K., Andersen, T., Norenzayan, A. 2016. Religious priming a meta-analysis with a focus on prosociality. Personality and Social Psychology Review, 20 (1), 27-48.

Shariff, A. F., Norenzayan, A., Henrich, J., 2010. The birth of high gods: how the cultural evolution of supernatural policing influenced the emergence of complex, cooperative human societies, paving the way for civilization. In: Schaller, M., Norenzayan, A., Heine, S. J., Yamagishi, T., Kameda, T. (Eds.), Evolution, culture, and the human mind. Psychology Press, New York, 119-136.

Soler, M., 2012. Costly signaling, ritual and cooperation: evidence from Candomblé, an Afro-Brazilian religion. Evolution and Human Behavior 33 (4), 346-356.

Sosis, R., Alcorta, C. S., 2003. Signaling, solidarity, and the sacred: The evolution of religious behavior. Evolutionary Anthropology 12 (6), 264-274.

Sosis, R., Ruffle, B. J., 2003. Religious ritual and cooperation: testing for a relationship on Israeli religious and secular Kibbutzim. Current Anthropology 44 (5), 713-722.

Spence, M., 1973. Job market signaling. The Quarterly Journal of Economics 87 (3), 355374. 
Sutton, R. S., Barto, A. G., 1998. Reinforcement learning: an introduction. MIT Press, Cambridge, MA.

Tan, J. H. W., Vogel, C., 2008. Religion and trust: An experimental study. Journal of Economic Psychology 29 (6), 832-848.

Tenenbaum, J. B., Kemp, C., Griffiths, T. L., Goodman, N. D., 2011. How to grow a mind: statistics, structure, and abstraction. Science 331 (6022), 1279-1285.

Trawick, M., 1984. The changed mother or what the smallpox goddess did when there was no more smallpox. In: Daniel, E. V., Pugh, J. F. (Eds.), South Asian systems of healing. No. 18 in Contributions to Asian studies. E.J. Brill, Leiden, pp. 24-45.

Venables, W. N., Ripley, B. D., 2002. Modern applied statistics with S, 4th Edition. Statistics and Computing. Springer, New York.

von Rueden, C., Gurven, M., Kaplan, H., 2008. The multiple dimensions of male social status in an Amazonian society. Evolution and Human Behavior 29 (6), 402-415.

Waring, T. M., 2012. Cooperation dynamics in a multiethnic society: a case study from Tamil Nadu. Current Anthropology 53 (5), 642-649.

Watts, J., Greenhill, S. J., Atkinson, Q. D., Currie, T. E., Bulbulia, J., Gray, R. D., 2015. Broad supernatural punishment but not moralizing high gods precede the evolution of political complexity in Austronesia. Proceedings of the Royal Society of London B: Biological Sciences 282 (1804), 20142556.

Whitehouse, H. 2000. Arguments and icons: the cognitive, social, and historical implications of divergent modes of religiosity. Oxford University Press, Oxford; New York.

Whitehouse, H. 2004. Modes of religiosity: a cognitive theory of religious transmission. AltaMira Press, Walnut Creek, CA.

Whitehouse, H., Lanman, J. A., 2014. The ties that bind us: ritual, fusion, and identification. Current Anthropology 55 (6), 674-695.

Widman, D. R., Corcoran, K. E., Nagy, R. E., 2009. Belonging to the same religion enhances the opinion of others' kindness and morality. Journal of Social, Evolutionary, and Cultural Psychology 3 (4), 281-289.

Wildman, W., Sosis, R., 2011. Stability of groups with costly beliefs and practices. Journal of Artificial Societies and Social Simulation 14 (3), 6.

Wilson, D. S., 2003. Darwin's cathedral: evolution, religion, and the nature of society. University of Chicago Press, Chicago.

Xygalatas, D., Mitkidis, P., Fischer, R., Reddish, P., Skewes, J., Geertz, A. W., Roepstorff, A., Bulbulia, J., 2013. Extreme rituals promote prosociality. Psychological Science 24 (8), 1602-1605. 
Younger, P., 1980. A temple festival of Mariyamman. Journal of the American Academy of Religion XLVIII (4), 493-517.

Zeileis, A., Kleiber, C., Jackman, S., 2008. Regression models for count data in R. Journal of Statistical Software 27 (8), 1-25. 